\title{
看護がめざす科学とは何か
}

\author{
樋口康子 \\ 日本赤十字看護大学
}

\section{Science That Nursing Desires To Be}

\author{
Yasuko Higuchi \\ Japanese Red Cross College of Nursing
}

\begin{abstract}
This article is a summary of the lecture given by Dr. Yasuko Higuchi, Chairperson of the Eighth Academic Meeting of the Japan Academy of Nursing Science Witch was held 3 December 1988 at Rikkyo University, Tokyo, Japan .

The lecture was presented, at first, about her recent observation of the nursing researches conducted in Japan, and she commented a lack of knowledges and skills of approaching the phenomena which nursing research subjected to. Thus, according to her, what type of science the nursing science desires to be is still not decided, and that kind of fundamental question ought be asked to find a common basis for the development of the nursing research.
\end{abstract}

\section{Abstract}

For the purpose of searching for the alternative and the frameworks possibly given for the creation of nursing science, the history of science from 6th to 19th centuries was briefly reviewed. In the review of the science history, objectives of science was defined: to find out the entire as well as detail existence of the nature; to clarify the principle and function connected with the nature; and to describe and explain phenomena as well as laws connected with the nature. In the review of the special features attached to the modren science, it was pointed out that up to the present the major scientific attepts were limited in the sphere of materialistic phenomena, somewhat physically obserbable and countable, and the methods and procedures used by the modern science were very effective for generralization of the phenomena and finding the general principles and laws related the nature. The weakpoints of the modern science, however, may be found in dealing with a particular individual of human beings, especialy in dealing with quality of his/her health conditions.

Nursing is a science which deals with health conditions of a particular individual, not only those quantity matters, but also those quality matters. Nursing Science intends to observe and investigate a particular human being at his/her full individuality, and tries to find out a most effective way of caring that particular individual. Nursing Science may be required to take consideration into particular conditions and phenomena emerged in a certain individual, even though they had been ignored by the modern science for its generalization. In that regard, the task of the Nursing Science is to pick up individual phnomenon already abandoned by the traditional as well as the modern sciences. 
In order to pick up everything connected with health conditions of a particular human being, what kind of scientific approaches shall be adapted by Nursing Science? What alternatives other than the modern science does Nursing Science have? What type of science does Nursing Science intends to build? Which direction does Nursing as a newly born science intend to develop?

These are questions raised, and it was suggested that for a newly born Nursing Science it is necessary to begin its scientific efforts from building the basic foundation of science, that is, to observe every phenomena related with a particular living object and to describe everything observed and noted as it is alive. These simple but steady scientific efforts are taken by J.H. Fabre and G. White, and their works set the basis for the development of the modren biological science. Any science has its own developmental stages and the modern science are the results of the developments achived by step by step efforts. You can not skip the ground works of observation and collecting data. You can not junp into theoretical conclusion of generalization without steady efforts of picking up and describing each of a particular object painfully observed. Science does require a series of methodological procedures and a certain trainings in respect of knowledge and skills. In this regard, Nursing Science is just newly born, and it needs the basic trainings of science. It is too early for Nursing Science to jump into theoretical conclusions. Nursing Science does need the ground works of observation and description, and collections of data and information regarding everything related with health conditions of human beings. Without these basic trainings and works, you can not generalize nursing facts and phenomena.

To build the ground works of Nursing Science, it was suggested to carry out: 1) the trainings of observation skills to see the nature objectly, in particular, to watch living objects vividly as they are alive; 2) the trainings of description skills in order to be able to describe the nursing phenomena, with the necessary skills required for preciseness, specification, summarization and noting of points; and 3) encouragement of more group discussions about what each nurse has observe and experinced in actual situation of nursing care, and more opportunities for feed-backs are urgently needed.

私共日本の看護界では, 最近, 研究が盛んに に行われております。看護がプロフェショナル と名のる以上，これは当然のことであり，しな ければならない大事なことだと思います。

しかし，その成果を見てみますと，果たして 研究の価値があるのだろらかと思われるものも 多々あるのが事実です。そのよらな研究をもら 少し深く見てみますと，研究のスタイルといら より, 何かもっと根本的な, 研究の対象に対す るアプローチの仕方に問題があるように思える のです. 要するに, 研究の対象にせまりよる姿 勢や方法に何か欠けているものがあるように見 えるのです. それは一体何かを考えてみました。

学んでいる間に，人間を対象とする看護者が， 科学したり研究するその方法は，いわゆる近代 科学がとっている研究の方法とは異なるのでは ないかと考党させられました，本日はそのあた りを試論ではありますが，ここにお話しさせて いただきます。

自然の現象を説明したり，自然の本質を求め る人間の努力は紀元前の古代から脈々と続いて
おります。

科学の歴史を振り返ってみますと, 古代にお いては，自然現象を説明しようとして，人間の 日常生活の中から体験的にものごとの本質をと らえよらとしていたようです.

例えば古代ギリシャではどらだったでしょら か.2つその例をあげてみます。

(1)哲学者であり数学者でもあったタレスという 人は，「水は万物の源である」と言って，自然 現象をすべて水から合成されたものとして説明 しました。この場合, 水といらのは神話的な水 ではなく，実体として経験的に受けとめた水を 物質的なものの根源とする唯物論的な立場をとっ ているよらに見受けられます。

(2)同じく古代キリシャの数学者ピタゴラスは 「自然は数なり」と言って, 自然の法則を数学 的に表現し, 幾何学的に関係あるものとしてと らえ，すべてを合理的に考えようとしました。 このように自然現象の本質を唯物的に，また， 合理的に考えよらとする人間の知恵は, 古代か ら脈々と継承されてきたものと思劣すす。 
同じ古代において，東洋ではどうだったので しょうか.

(1)東洋の中国では, 陰・陽 5 行説が自然を説明 するため盛んに使われていたそらです。これは 天体や地上や人間に関するすべてのものの性質 や運動は，陰と陽といら 2 つ相反する性質や 動さとして，末た，木・火・水・金といら元素 から成り立っていると考学られていたようです。 すなわち，木は植物，それに火，水，土壤，鉱 物といった $5 つ$ の原素の性質から成立してい屯 す.

陰・陽 $2 つ の$ 相反する性質や動きを説明した ものには，例党ば男女の関係を，男は陽で女は 陰, 左右の関係を, 右は陽で左は陰, 形の関係 を, 丸は陽で四角は陰, 数の関係を, 偶数は陽 で奇数は陰, 植物の関係を, 木は陽で草は陰, 天地の関係を, 天は陽で地は陰, 月と太陽の関 係を，太陽は陽で月は陰，のように説明してお りました。

このよらなことから，中国における古代の人々 は，自分達の身の回りの自然を自分達の生活の 中で, 自分達の感覚を通して，見たり，聞いた り，匂いを嗅いだり，触ったりしながら，体験 したことを基にして，自然を説明しようとして いたことがわかります。

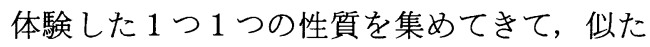
もの同志を類別し，陰と陽と名づけたように， 何かその根底には現在の自然科学の出発点となっ た人間の知恵が秘められているように思克すす。

このよらにして, 古代には西洋でも東洋でも， 物質を，自然界を説明するときの根源とする唯 物的な考方方が見られました。 また，自然減少 を説明するときに，表現しやすい数字でまとめ たり，幾何学的な関係に結びつけたり，似たも の同志を類別して名前をつけたりする合理的な 考方をしていたことが明らかです.

また別の側面からみると, 自然界の中の多種 多様な存在も，基をたどるときわめて数少ない 物質, すなわち, 水, 火, 木, 土, 鉱物, など に還元してしまうという思想があったとも考え られるのです。
ところで中世における科学観はどうだったで しょうか．中世に打ける科学観はキリスト教的 偏見の下にあって，自然界のありのままの姿を 身ようとしなかった為, 「科学の暗黒時代」と 言われております。ししこの「科学の暗黒時 代」は，それなりに，後に続く時代のために大 いに意味があったようにも考它られるのです。

中世から近代科学への移行期について, 東大 の村上陽一郎教授は, 彼が書かれた「新しい科 学論」の中で,「中世のキリスト教的思想が, 逆にこれを吹きはらおうとして，ヨーロッパで 自然科学が誕生したのである.」p.110と述べ ておられます。

さらに村上教授は，この時代に科学者として 活躍した人々のらち，ガリレオ（加速度の概念 や落体の概念を確立, 惰性の法則をとらえた, 望遠鏡ではじめて天体の観測をした）や，ケプ ラー（楕円や面積の法則などを確立した）の言 葉を引用して，「これらの人々はいずれも熱烈 な宗教家で, 神が創造した自然とは一体何かを 見極めようとしたすすなわち，この世界を合理 的に創り上げたキリストといら偏見をもってい たからこそ，自然科学的真理を得たのである.」 p.110と結んでおられます.

17世紀の後半から18世紀にかけて，歴史をた ぞってみますと，「(自然こそ(神)そのもので ある」と唱える理神論者, 「(自然)を(神)と呼 ぶ必要はない」と強調する無神論者, あるいは 啓蒙主義者などの出現によって，(神)のことは 故意に忘れさろらとした聖俗革命がおき，人々 は次第に人間自身と自然との間に距離をもつよ らになりました。

これは，人間が，自然から遠く離れたところ から, 自然を客観的に眺め, その自然の姿が何 か, ぞんな構造をもつものか，人間の理性的な 認識活動によって自然の現象を普遍化させてい こうとするものです.

この自然をわかろうとする典型的なものが, かの有名なニュートンの力学です.ニュートン 力学の本質は運動の法則と万有引力にあります. それは，地上においてリンゴが落ちるときの減 少 (等加速度)が, 天体にある惑星の楕円運動と 
同じ種類の減少であることを明らかにしたもの です.

このように，この時代を代表するニュートン は，天体と地上とは同一の力学的法則の支配を 受けていることを明らかにしをした。また，力 学の体系は 3 つの基本概念, すなわち, 時間・ 空間・質量を基礎にして数量的に表わすことが できることを打ち出しました。速度とは距離を 時間で除したものであり, 力は質量 $\times$ 加速度, あるいは，運動量とは質量 $\times$ 速度であると定義 したりいたしました。

このようにして，自然科学の概念について， 自然界は，すべてが，ある法則性から成り立っ ており，秩序あるものであると考光るようにな りました。

このように普遍化していく過程では, その現 象を分析し, 要素に還元し, その要素がぞらい ら法則に従って配列されているか, その構造が どのよらにつくられているかを把握していく方 法が用いられます。それによって，この普遍性 は, 時や場所や人を問わず, 同じ現象を再現し 得ることを条件に決められていきます。

しかし, 後の世代になって, 徐々にこの普遍 性にそぐわないもの, 普遍性からこ泳れるもの が明らかにされはじめました。

もら少し異なった側面から明確に表現してみ ますと, あるいくつかの現象の間に共通な普遍 性を求める時, その普遍性に欠けるもの, 普遍 性からこぼれ落ちるもの, 要するに抽象化でき ないものは, もともとその系列から切り落とさ れていたのではないかと思らのです.

その例を 1 つし上げてみたいと思います。 私は物理学のニュートンの引力, あるいは地 球の引力の法則とは全く正反対の現象を体験し たことがあります。米国のカリフォルニア州ロ スアンジェルスにサクラメントといら村があり ます(サクラメントは, トマトジュースの生産 で有名です)，そこにある「不思議なスポット」 を訪れた時の話です。ロスアンジェルスの町か ら 1 時間程バスにゆられて行き, 国道からはず れて林の中に入り込んで，しばらく行きますと， 小さい山のふもとにたどり着きます，その山の 中腹には, $20 \mathrm{~m}$ 四方くらいの木の小屋が山の斜
面に平行して建っています，そして小屋の入口 は斜面の上の方にあり，出口は斜面の下の方に あります。ですから，斜面の上の方にある入口 から入って, 斜面の下の方にある出口に向かっ て歩いていけば当然下山のかたちになります.

この山の斜面の上の方にある入口から入って 小屋の入口から出口にかけてついている手すり につかまりながら出口の方に向からのですが， 妙に後から引っぱられてなかなか前に進めませ ん. 手すりから手を離しますと，山の上の方に 途端にころがり落ちてしまいました.山の下か ら上の方にころがり落ちたのです. 何とも不思 議なスポットです. 何か仕掛けがあるのではな いかと小屋番の人に根汪り葉汪り質問しました. でも，そこには種も仕掛けもないことがわかり ました。

ですからこのスポットだけは, あれほど真実 だと思われていたニュートンの引力の法則は全 く当てはまらないことになります.

しかし，ニュートンが引力の法則を打ち出し たときは，このようなスポットはもともとはじ めから切り落とされて問題にされなかったに違 いありません。

要するに, 歴史の上でガリレオ以来, 自然に 対する追究は, 「個別については語り得ない」 という立場に立ち，すべて数量的に測定でき， 分析したり, 総合したり, 実験したりして普遍 的に打ち出せるものが近代科学的認識の対象に なってきたと言えるのではないでしょらか.

講演が始まって以来15分になりますがこの間, 歴史的な流れをお話ししてきましたのは，この 点を強調したかったからでございます，要する に, 近代科学の考方方では「個別については語 り得ない」という点が強調されていることに留 意したいと思います。

このようにして近代科学の思想に基づいて, 世の中のあらゆるさまざまの現象を明らかにさ れていくにつれて, 従来の近代科学の考方方で は説明でさ得ない現象に気づきはじめ, 多くの 批判の目が集中しはじめたのです.

最近の科学論の動向を捲りますと, 近代科学 に緾わるいくつかの疑問が出てまいります.

例えば， 
(1)科学とは，その対象を理性的・客観的に眺め, それが何かを説明することであるとは言われて いるが，観察するのは人間の目であります。人 間の見方にはおのずからその限界があります. ひとつの例をあげてみますと，ある側面に集中 している時は，同時に他の側面を見たり考えた りすることは難しい，例えば私の講演に集中し ていられる方々は，隣の人が眠っていることに は気がつかないでしょら。

(2)科学は.ある現象や実体を認めることからは じまると言われています。しかし，人によって， その実体の存在を認めない人と認める人とがい る場合, 科学は成立するのでしょらか.

(3)実体とは一体何なのでしょうか. 実体の存在 があるとしても，人それぞれのとらえ方が異な ります。認識の仕方が異なりをす。これをどう 受け止めたらよいのでしょららか. どら解釉し ていけばよいのでしょらか.

(4)今までの近代科学，すなわち，「個別につい ては語り得ない」といら考方方で, 看護の対象 者である人間を考学ることができるのでしょら か.

(5)人間を科学の対象として考えると，あまりに 複雑で, 形体や数字や運動として示すのが困難 です.そのよらに示すことがでさないものは科 学といえないのでょらか.

(6)もし科学といえないとすると，人間を対象と する領域は学問とはいえないのでしょらか.

このような疑問が沸々と起こり，今や人間を 対象とする学問の領域では, どのようにその現 象を理解していったらよいのか, 混沌とした状 態の中にあるといっても過言ではないと思いま す.

さて，このよらな疑問が何故あがってくるか といいますと, 私共看護専門家は人間を対象と してその役割を果たさなければならない仕事を 持っています．私共看護専門家は, 看護といら 現象をどうとらえていけばよいのかといら点か ら出発しているのです.

今をで括話ししたように, 近代科学的な方法 でとらえることが重要なのでしょらか。 ある現 象をとらえるといえば，すぐ自然科学，特にニュー
トンの時代の近代科学と結びつけてしまう私達 がいるのではないでしょらか. 近代科学の方法 論によって自分自身をがんじがらめにしばり上 げ，身動きできないでいる私達がいるのではな いでしょらか.ここで少し違った角度から，私 達, 看護学の位置づけを試みたいと思います。

\section{看護学の位置づけ}

さて皆さん，「学問の地図」(1979年朝日新 聞社発行)といら本のあるのをご存じですか. この本はとても興味深い本です，この本はさま ざまな専門領域の人々, すなわち, 自然人類学, 哲学, 動物学, 生物物理学, 植物学, 科学史の 各領域の方々が集まって, 科学や人間について 議論されそそれをその議論のまままとめたもの です.

その中で哲学者である上山春平氏が，全部の 学問を大きく, (自我学) (普遍学) (地球学) と 3 つに区別して考えてみることを提唱されました.

1) 自我学といらのは哲学のことです.ソクラ テスが「汝自らを知れ」，またデカルトが 「コギト エルゴスム：我れ考光る故に我れあ り」といったように，外に目を向けないで，自 分自身を見つめるところからはじまる学問のこ とです.

哲学以外の汪とんどのサイエンスが，自分以 外の外の世界を対象としているのに対して, 哲 学は自分の足元を研究するセルフ・サイエンス であり，自我についての学問といえましょう.

2 ) 普遍学といらのは, 物理学に代表されるユ ニバーサル・サイエンスのことで, 外の世界の 現象を何でも対象とする構えをもっていすす.

物理学は, 直接的に経験的なものを全部捨て 去って，その現象を基本的要素にまで還元して 行き, その要素がどらいら法則に従っていくか を把握していきます。例えば，ある現象につい て質量といら普遍的な指標を決めて, その法則 を探します，具体的にいうとニュートンの運 動の法則を方程式に従って質量に還元するといっ たよらなことです.

また, 物理学は非常に遠いところ, 例えば, 天体の運動をむずとらえて，その天体の運動か ら地上の運動を理解していきます。これもさき 
ほどニュートンのところでお話ししました。

普遍的な法則を求める物理学は, 技術と結び ついて巨大な成功を预さめました。

ここで大事なことは, 物理学が近代科学の中 で一番最初に模範的な形で体系化されたので, 他の科学は物理学に近づくことを目標にして進 歩してきたのではないかといらことです．そう いらことで, 物理学は学問の王様といわれてい ます.わたくしどもには, 物理学と同じ考方方 でいくことが学問をすることだと思い込んでい る傾向があります.

3 ）地球学といらのは, 上山氏によれば, 自分 自身を見つめる自我学と, 遠い天体など宇宙一 般の法則を探る普遍学の中間にある経験科学を さしています。

経験科学は, ルネッサンス以後, レオナルド・ ダ・ヴィンチなどの寄与により起こってきまし た. 地質の研究, 潮の満ち干の計算, 人間の身 体のメカニズム, 要するに人間の身近にあるも のを手がける学問です. 今日の生物学, 環境学, 人間諸科学は全部この地球学の範疇に入ります.

上山氏は, これら自我学, 普遍学, 地球学の 関係を, 三角形で表わされました。

三角形の底辺には, 物理学で代表される普遍 学があり, 三角形の頂点の点にあたるところに あるのがセルフ・サイエンスの哲学です，底辺 の物理学は, 宇宙全体を相手にして, 無限大の キャンパスを相手に普遍的な法則を探求します. それに対して，三角形の頂点は宇宙に比べると， 小さい自分自身の中へ深く入っていきます.

底辺と頂点の中間にあって, 限られた枠の中 で，人間の目に見光，また，体験できるものを 取り扱らのが地球学なのです. その中には, 植 物学, 動物学, 地質学, 社会学など様々な領域 の学問が入ります.

問題は, 人間学や人間諸科学がどこに位置す るかです.

上山氏は「学問の地図」なかで, 地球学の一 部としての人間学を等身大の学問と呼んでいま す.そしてとても興味深い発言をしていすす.

「医学のような地球上の身近な等身大の学問に, 人間の生死がかっているとすると, これは学 問の見方の大きな転換を必要としている．今ま
で遠い方に重点がかかっていたのが，近いやつ に重点をかけることになる. 西洋人の作った科 学の体系では身近な学問はランクが低かった.」 p.217〜220と面白いことを述べていられます.

さて, 医学や看護学はこの三角形の図形のど こに位置づくでしょらか.

医学は元来病気で困っている人を相手にして, 人間の体の病気の部分を治療する身近な学問で すが, 今日では, 生命科学の最先端を研究し, 生化学や分子生物学を普遍学的方法によって, 細菌やヴィールスのメカニズムを解明すること や, 人間の卵子や精子を人間の体から取り出し て, 試験管の中で結合させたり, 一人の人の体 から藏器を取り出して他の人の体に移植したり することを重要視しているように見えます。

この様子を見ていると, 身近な人間のケアよ りも, 病気についての認識を普遍科学のもつ分 析的な方法で発見し, 治療し, 調整していこう とする方向へ傾いています。白意味では, 三 角形の底辺の普遍学の方に追従しているのです.

それに対して, 看護は対象者一人ひとりにつ いてAさん，Bさんといら固有名詞をもつ人間 を中心に，その人の病気がその人にどら影響し ているか, 精神的な安定度の問題, 家族と本人 との関係の問題, 社会とのつながりの問題, そ の人の価値観, その人の習慣, その人の人格, その人の生活スタイルなどを考慮しながら，そ の人の全体像を描き, その人が人間らしく健康 な生活をおくることができるようにケアするこ とを焦点にしています.

これこそ等身大そのものの学問であり, その 人の全体像に迫る学問であります.

それは，何か特別な実験をして，普遍的な真 理を発見するというものではなく，一人ひとり の身の回りに起きるできごとを全般的に取り扱 ら日常性の科学です.

看護学は, 物理学のような普遍性を求める学 問が切り捨てたものを拾い上げて活かしていく 学問かもしれません.

物理学が成功し，いまだに学問の王様といわ れていますが，その取り扱ら対象は極めて限ら れており, 再現することの可能な, いわゆる時 間と場所の変化をもつ歴史の概念の入らない普 
遍的なものに限られています。

看護学は生きた一人ひとりの人間を, 固有名 詞で時と所を明記しながら, その人に関わる現 象を記述して, その変化を追求します. 看護学 は, 物理学が普遍的な法則を求める故に切り捨 てた，時間と場所と人間を明記しながらとの全 体像を描こうとしています。

その意味では, 物理学から一番遠いところに いる看護学こそ, 各々のケースがもつ固有性と, そのケースがもつ歷史的変化をとらえることが できるかもしれません。

看護が人間をどのようにとらえたらよいのか ……とのアプローチや方法を考光る手がかりと して，生物学がどういう方法をとって生き物を 研究しているのか見てみたいと思います．物質 を取り扱う物理学ではなく, 生命や生き物を扱っ ている生物学がとっているアプローチから何か を学ぼらとといら訳です。結論から先に申し上 げますと, 私の個人的な見解として, 看護は博 物学的な方法やアプローチへと進んでいくこと を提唱してみたいのです.

「博物学」というのは, 生き物を中心に自然 を観察し，その多様性をこまかく客観的に記録 する学問です.そして，その記録として集めら れたもののことを「博物誌」といいます.

今の日本の看護界でどらいう「博物学的方法」 が必要か考えてみをした．博物誌をまとめた生 物学者は大勢いますが，私が考えているのは 「近代的な分類学」を樹立したスウエーデンの リンネのような大学者ではありません. 生物の 「分類学」を体系づけたという偉大な功績は, 逆の見方をすれば，自然を人工的に構築したこ とになります。事実，リンネが描く自然はいさ さか人工的に整理され過ざているという批判が あります。

今の私共看護専門家がすべきことは，私共の 身の回りにいる人間, 特に看護の場でケアする 対象者を人工的に整理したり，分類したりする ことではありません，また，人間についての知 識を体系づけることてもありません，学問とし て出発しようとしている今日の看護は, とても そんな段階に到達していないと思います。あり きたりの言い方をすれば, 看護科学の概念を作っ
ていく段階にあると思います，正直にいって， まだ，科学的なものの見方を訓練する段階であ り，事実をできるだけありのまま観察したり， 収集したりするスキルを養ら段階であると思い ます，そして，事実や現象についての記述やデー タを収集する大切な時期だと思います。このよ らに, 基礎的な訓練やデータを集める出発の大 事な時に, その過程を越えて, モデルだとか理 論だとかあまりにも飛びつき過ぎると思います。 これは, 科学や学問が一歩一歩の積み重ねから 成立することを無視するようなものです.

さて，私が頭の中に描いている博物誌は, 18 世紀から19世紀にかけてヨーロッパで生れた庶 民の博物誌です。自分達が生活している日常の 周辺に対象をしぼって, 特定の種類の動物や植 物の生態をありのまま観察して, 丹念に記述し て記録に残していった人達のことです.

例㓪ば,「セルボーンの博物誌」を書いたホ ワイトや，有名な「昆虫記」を書いたファーブ ルのような人達のことです.

「セルボーンの博物誌」を書いたホワイト (1720〜1793)は，イングランド南西部，サウサ ンプナクのセルボーンで生まれ，オックスフォー ド大学を卒業すると, 73才で死辸故郷のセ ルボーンで, 教会の牧師として変化のない平穏 無事な一生を送りをした.きわめて平凡な生活 の中で，ただ一つだけ非凡なことを成し遂げま した．それは地元り自然を一つ一つ丹念に観察 して，発見した事実を手紙に書いて二人の有名 な博物学者へ送り続けたことです. それらの110 通に及ぶ手紙をまとめたものが「セルボーンの 博物誌」として出版されました。いわば素人が 書いた自然観察の記録であり，その観察の対象 は自分が住んでいた周辺に限られています。

私達, 看護の現象を追究しようと思う者は, その現象が繰り広げられている場所で, その現 象を，対象者と環境まるごと，記録に残して記 述していくことです. 私共がケアしているケー スは，私共以外の誰によっても書くこときでき ないのです. 看護科学は, 大学や大学院や研究 所の建物の中だけで作り上げるわけにはいきま せん. 看護の現象が繰りげられている場の記述 や記録から生れるものなのです. 今という時に, 
その病院で，その病室で起こっていることは二 度と同じことを繰り返しません，『その時，そ の現象を観察し, 記述し, フォローして観察し, 記録に残す。』その記録がたまり，あるケース の歴史的変化の全体像を示す貴重なデータとな るのです.

「セルボーンの博物誌」は, 自然観察と文学 を結びつける役割を果しました。文学は，もの ごとの客観的な記述とともに人間の感情・感動・ 考えていることを言葉で表現することです，そ のような博物誌をイギリス人は貴重な財産とし て大切にし，誇りにしています，そして，博物 誌はイギリス人の動物に対する愛情, 自然に対 する愛着を表現するものとて, 共感を呼ぶもの となっています。

「セルボーンの博物誌」を書いたホワイトや 「昆虫記」を書いたファーブルは，生物をあく まで生きたまま，それも自然の状態で観察して います.ファーブルは, 近代科学が科学の成立 に不可欠としている実験らしいことを何一つと してしていませんが，彼の「昆虫記」は立派に 「科学することの成果」を後世に残しています. 彼等にとって生物は何よりも愛すべき存在でし た. 文字通り「生さ物」への愛情が科学するこ とへの興味を駆り立てる源でした。生物学の専 門家が客観的に説明しようとして，化学元素の 記号や数字で表わす研究発表論文よりも，よほ ど「生きているもの」をそのまま生き生きと私 達がわかるように記述しています。

「昆虫記」を書いたファーブルは, 同時代の フランスの代表的科学者パスッールに対して, ことの淁か強い感をもっていたと伝えられま す. その理由は, パスッールがカイコの伝染病 の研究をしながら，カイコそのものについては 知識をもっていなかったからだと言われていま す.

最近の科学は, 近代科学の方法によって生命 現象の共通面や普遍性を解明するのに熱心です. そのため, その生命現象や生き物の具体的な姿 を無視することさえあります.看護者は, 仕事 の中で，対象者について具体的なことをたくさ ん知っています。今まで近代科学はそらいう対 象者への共感や愛情を捨てて, 客観的に観察す
ることを教えてきました。しかし，今まで捨て てきたもの，それを拾い上げて，主観的にでも よいから観察し, 記述し, 記録をとり, 対象者 の全体像を描き，その人だけがもつ正体に迫っ ていく，新しいタイプの科学を看護がめざして いくことを希望しているものです.

その為には，ただ看護の現象を眺めれば誰で も追究できるというのではなく，大事なことは その素地をもたなければなりません.

その素地を作る為には，

(1)看護の現象に迫りよる能力を作ること．要す るに現象の成り立ちを思考する論理構造を学習 すること.

(2)看護の現象を記述することの方法と，表現す る適切な言葉を見つけ出すこと, 近代科学が捨 て去ったもの，それが一体何なのかを言葉で表 現していくことです.

(3)看護の現象を記述する時に，どんな知識や経 験がその根底にあって，そのような表現をして いるか根拠を明確にすることです，それには一 般教育科目，医学系その他あらゆる基礎になる 知識が必要となってきます。

看護の現象を記述する方法や，記述した結果 や，記述したその根拠など，相互の違いや類似 点なとを議論しあらことが，このような学会の 存在価值でもあるのではないでしょらか.

以上, 科学の歴史をたぞり, 近代科学の考兄 方を述べ，そして看護の学問の位置づけを試み， 看護の科学をどう考えたらよいかを, 試論です がお話してみをした。ご静聴ありがとうござい ました。

\section{参考文献}

アンバシェ, M. : Les Philosophier De La Nature, 1961, 桐山 稔訳, 自然の哲学, 白水社, 1975 . ブラウン, H.I. : Perception, Theory and Commitment, 1977, 野家啓一・伊藤春樹訳, 培風 館, 1985.

ブロノフスキー, J.: The Common Sense of Science, 1951, 三田博雄, 松本 啓訳, 科学とはなに か, みすず書房, 1968.

ブロノフスキー, J.: The Identity of Man, 1965, 松本 啓・森松健介訳, 人間とは何か， 久す 
ず書房, 1969.

ブロノフスキー, J. : Science and Human Values, 1965, 周鄉 博訳, 人間の発見と創造, 講談 社現代新書, 1966 .

ファイアベント, P.K.: Against Method-Outline of an Anaechistic Theory of Knowledge, 1975 , 村上陽一郎・渡辺 博訳, 方法への挑 戦一科学的創造と知のアナキーズム, 新曜社, 1981.

ファイアベント, P.K. : Science in a Free Society, 1978，村上陽一郎・村上公子訳，自由人のた めの知, 新曜社, 1982 .

ファーブル, J.H.: Souvenirs Entomologiques, 1900, 山田吉彦訳, ファーブルの昆虫記上, 岩波少年文庫, 1953 .

ファーブル, J.H.: Extrait de “Souvenirs Entomolog iques”, 1900, 林 達彦訳, 昆虫と暮らして, 岩波少年文庫, 1956 .

ハックスリ・コリングウッド・メルローポティ:

Evolution and Ethics 1894. The Idea of Nature 1945. “Le Concept de Nature”, 1968, 菊川 忠夫編訳, 自然の哲学一自然の中の人間と人 間の中の自然, 御茶の水書房, 1981 ハソソン, N.R.: Patterns of Discovery, 1958,

村上陽一郎訳, 科学的発見のパターン, 講談 社学術文庫, 1968 .

石本巳四雄 : 科学を志す人々へ, 講談社学術文庫, 1984.

板倉聖宣 : 科学の学び方・教方方, 太郎次郎社, 1975.

板倉聖宣：科学的とはどういうことか, 仮説社, 1977.

カプラ, F.: The Turning Point-Science, Society, and The Rising Culture, 1982, 吉沢伸逸他 3 名訳, ターニングポイントー科学と経済・ 社会, 心と身体, フェミニズムの将来, 工作 社, 1984.

メダウオー, P.B.: The Limits of Science, 1984,

加藤珪訳, 科学の限界, 地人書館, 1987.

森岡正博: 生命学への招待一バイオエシックスを

超元て, 勁草書房, 1988.

クーン, T.S.: The Essential Tension, 1977, 安 孫子誠也・佐野正博訳, 本質的緊張 I, み
すず書房, 1987 .

クーン, T.S.: The Structure of Scientific Revolutions, 1962, 中山 茂訳, 科学革命の構造,

みすず書房, 1971

村上陽一郎：新しい科学論一「事実」は理論をた おせるか，講談社， 1979

村上陽一郎：動的世界像としての科学, 新曜社, 1980 村上陽一郎：科学のダイナミックス, サイエンス

社, 1980

村上陽一郎: 科学・哲学・信仰, 第三文明社,

1977

村上陽一郎：歴史としての科学, 筑摩書房, 1983 村上陽一郎：科学と日常性の文脈, 海鳴社, 1979 村上陽一郎: 現代科学論の系譜, 数理科学,

(188)，56〜59頁, $1979 ・ 2$.

村上陽一郎・中村雄二郎 : 変貌する「知」のトポ

ス, 現代思想, Vol. 11-1，48～78頁, 1983.

村上陽一郎 : 科学史の現在, 現代思想, Vol.8-4,110

$\sim 119$ 頁, 1980

中村雄二郎 : 哲学の現代, 現代思想, Vol.8-4,42 56

頁, 1980

中谷宇吉郎：科学の方法, 岩波新書, 1958

澤潟久敬：哲学々科学, 日本放送出版協会, 1967 ピアジェ , J. : Introduction-The Place of the Science of Man in the System of Sciences, 1970, 波 多野完治訳, 岩波書店, 1976 .

ポアンカレー, H.:La Science of Hypothése, 1902,

河野伊三郎訳, 科学々仮説, 岩波書店, 1938. ポアンカレー, H.: La Valeur de La Science,

1905, 吉田洋一訳, 科学の価值, 岩波書店, 1977.

ポパー, K.: Unended Quest, An Intellectual

Autobiography, 1974, 森 博訳, 果しなき 探求一知的自伝, 岩波現代選書, 1978 ラカタッシュ, I. : The Methodology of Scientific

Research Programmes, 1978, 村上陽一郎他 訳, 方法の擁護一科学的研究プログラムの方 法論, 新曜社, 1986.

ローダソ, L. : Progress and Its Problems-Towards a Theory of Scientific Growth, 1977, 村上 陽一郎・井山弘幸訳, 科学は合理的に進歩す る一脱パラダイム論へ向けて, サイエンス社, 1986. 
ロジャーズ, E.M.: A Science of Unitary Human

Beings, 1984年カナダに㘧ける看護理論家カ ンファレンスより録音, 加藤道子訳, 1 単位 として機能する人間の科学一看護のパラダイ

ム, 18〜 51頁, 看護, Vol.36 No.11, 1984.10. ルヴォフ , A.：L'ordre Biologique, 1962, 松代

愛三・下平正文訳, 生命の秩序, 久すず書房, 1973.

坂本百夫：新しい認識論への試み, 数理科学, (240), 53〜60頁, 1983.7 .

スノー, C.P.: Two Cultures and Scientific Revolution, 1959, 松井巻之助訳, 二つの文化と科 学革命, みすず書房, 1960.

シュレデンガー, E. : What is Life?-The Physical

Aspect of the Living Cell, 1944, 岡 小天 • 鎮目恭夫訳, 生命とは何か一物理的にみた生 細胞, 岩波新書, 1951 .
田辺 元: 科学概論, 岩波書店, 大正 7 年 ホワイト, G.: The Natural History of Selborne, 1789, 西谷退三訳, セルボーンの博物誌, 博 友社, 1958 .

山田慶児 : 学問の地図一人間学への試み, 朝日選 書, 1979 .

吉仲正和：ニュートン力学の誕生一現代科学の原 点をさぐる, サイエンス社, 1982.

米本昌平 : 生物医療の社会受容々生命観, 現代科 学, $20 \sim 24$ 頁, 1984.5 .

米本昌平: バイオエシックス考, からだの科学, (129), $6 \sim 9$ 頁, 1986.

湯川秀樹：目に見光ないもの, 講談社学術文庫, 1976.

湯川秀樹・梅棹忠夫：人間にとって科学とはなに か, 中央公論社, 1967. 